\title{
Presenting a Conceptual Model for Corporate Innovation in the Insurance Industry by Structural Equation Modeling: A Case Study in the Iranian Insurance Industry
}

\author{
Fatemeh Mirzaei Rabor \\ M.S. of Entrepreneurship Management, Faculty of Entrepreneurship \\ University of Tehran
}

Hossein Safari (Corresponding author)

Associated Professor, Faculty of management

University of Tehran, Tehran, Iran

E-mail: hsafari@ut.ac.ir

Tahereh Keshavarzi

M.S. Candidate of business Management

University of Tehran, Tehran, Iran

Abdol Hossein Jafarzadeh

M.S. Candidate of Industrial Management

University of Tehran, Tehran, Iran

Received: March 29, 2013 Accepted: April 14, 2013

doi:10.5296/ber.v3i1.3445 URL: http://dx.doi.org/10.5296/ber.v3i1.3445

\begin{abstract}
The aim of this paper is "presenting a conceptual model for Corporate Innovation in the Iranian Insurance Industry". Statistical community of this research includes Iranian insurance industry
\end{abstract}


and academic experts. Accordingly, first, by studying the literature and background of the subject, 35 subsidiary factors of this structure were defined and after doing some interviews with experts, these factors decreased to 16. Then, questionnaires were distributed among Iranian insurance industry's experts. Then, 269 filled questionnaires were collected. Next, Factor Analysis and Structural Equation Modeling were used to discover the conceptual model; as a result, the proposed model was extracted. Our finding has been the design and modeling of factors affecting innovation performance of firms in the insurance industry.

Keywords: Innovation, Insurance Industry, Factor Analysis, structural equation modelling (SEM).

\section{Introduction}

Key feature of the current business environment is rapid and deconstructive change. In this space, industrial and service enterprises are in interaction with a competitive environment the main features of which are complexity, dynamism and unpredictability (Loalie and Telia , 2006).

Due to rapid changes in technology and increasingly intensified competition, the economic context of the business environment has undergone major developments, so that today the term "network economy" is used to introduce the new economy. Two main features of network economy are being "knowledge based" and "based on cooperation and synergy" of economic activities in this new space is (Nicksir, 2007).

As was expressed, in the 21st century competitive environment of organizations will be completely different from the prevailing conditions in the twentieth century. U.S. National Academy of Sciences with the aim of investigating the nature of this transformation and its effect on future industrial activity developed and implemented a research project entitled "Challenges Facing Production Prospects in 2020". According to the report of this research, perspective of the main factors affecting production in2020 is depicted as follows (OECD, 2004):

1. Due to the development of communication and sharing of knowledge, competitive environment requires rapid response to market forces.

2. Alert and informed customers expect ordered products to be compliant with their requirements.

3. Creativity and innovation is the basis of competition in all aspects of production.

4. Development of the technology of innovative and creative processes has transformed the domain and scale of production.

5. According to the global ecosystem conditions, protecting the physical environment a fundamental principle. 
6. Information and knowledge required about the various aspects of production and market conditions are broadly available for decision making.

7. Global distribution of production resources is a key factor in organizing productive enterprises.

The major challenges facing manufacturing in 2020 include: achieving simultaneity in planning, design and production operations, integration of human and technical resources in order to promote workforce performance and satisfaction, continuous conversion of data gathered from multiple sources into useful knowledge for effective decision making, adaptability of product and manufacturing system process with the physical environment, reconfiguration of production organization in response to changing needs and opportunities and development of innovative manufacturing processes.

Studying the above cases shows that an effective response to the main part of these challenges without considering the role of innovation and entrepreneurship would not be possible. These days, to face the competition ruling the market, factors of quality, cost control, having more resources, or having a better share of the market are not sufficient. Today, that knowledge-based paradigm rules the organizations, innovation is considered to be one of their superiority factors in the competitive environment. Below are the key factors for success in innovation (Langfield and Wirth, 1992):

$\checkmark$ Technological and economic environment (government assistance, state laws, size and expansion of the potential market, competitive intensity, largeness or smallness of the organization...).

$\checkmark$ Organizing innovation in the organization (how to control and encourage innovation, flexibility of the organization, the relationship between research and development and marketing...).

$\checkmark$ Major features of innovation (new product features, price, communication, distribution...).

$\checkmark$ Innovation project implementation (effective planning, presence and role of project manager, commitment to the prescribed time, cost, goals, and the amount of available resources ...).

Since under the current condition the approach of most top world organizations and companies has shifted towards knowledge and creating innovation, knowing the factors that have direct or indirect impact on innovation is very important. If the innovation environment is in the form of an accessible model, on the one hand, we can identify the factors affecting innovation and, on the other hand, by manipulating these factors, the effects on innovation can be measured.

Insurance industry in Iran according to the frameworks defined by central insurance has certain restrictions so that real competition is not possible for them. In this business environment, even pricing the services as one of the main levers in creating competition is beyond the control of the companies. Under these conditions, innovation is also affect and faces special problems.

This study calls for a model designed to introduce the factors affecting innovation in the insurance industry in Iran. The aim of this paper is presenting a Conceptual Model for Corporate Innovation in the Insurance Industry. This study was using second source data and 
case study. First we studied literature of Innovation, Insurance industry, and searches about them in Iran. After reviewing the literature and identification of indicators, 35 subsidiary factors of this structure were defined and after doing some interviews with experts, these factors decreased to 16. Then, a questionnaire among Iranian insurance industry's experts was distributed and 269 questionnaires were completed.

At the end Factor Analysis and Structural Equation Modeling were used to discover the conceptual model; as a result, the proposed model was extracted. Our finding has been the design and modeling of factors affecting innovation performance of firms in the insurance industry.

\section{Literature Review}

Jonathan Huggs in explaining the extreme weakness of neoclassical economics attitude towards the entrepreneurial phenomenon, states that entrepreneurship as the strongest, soundest and most complex phenomenon during the lifetime of the science of economics has remained quite neglected in the mathematical attitude governing this science (Chen et al.., 2004). In this regard various scholars in economics and management sciences have presented their theories in the form of different schools the most important of which include: School of Chicago by Knight, School of Germany by List and School of Austria by Schumpeter and later by Hayek and Kirzner. Meanwhile, the Austrian school refers to innovation and entrepreneurship as the main factors of production in national economy.

Austrian school is inspired by Schumpeter's views. In Schumpeter's perspective, entrepreneurship is the process of providing a new and different mix of resources in order to present new ideas to the market. So the entrepreneur intended by Schumpeter is an innovator who through replacing the existing firms or ideas with new firms, products or processes is trying to disturb the existing order and create a new order. This process is a dynamic process because along with the efforts of entrepreneurs to present innovations to the market through replacement of non-competitive businesses (including products, services or processes), a lot of pressure is imposed on the existing enterprises to become competitive. These kinds of entrepreneurial actions lead to economic change (Zhong and Yang, 2007) .

Schumpeter describes the creativity used in creating economic development as "entrepreneurial". Also "Mechanisms of economic development in capitalist society" rely on "entrepreneurial activities" (Shu-Hsien et al., 2008).

According to Schumpeter, entrepreneurship is a process which includes various duties or functions. In this perspective, entrepreneurial functions will include individual actions that lead to presenting new ideas to the market. Form of entrepreneurship process encompasses "entrepreneurial function" that includes determining new mixtures and incorporating leadership in order to profit from it (Jeong-dong and Chansoo, 2006).

Austrian school of economics was formed in the 1870s with the works of Karl Menger "was formed and later expanded by scholars such as Ludwig Mises, Frcedrich Hayek and Israel Kirzner. Although Joseph Schumpeter's view differs from the Austrian school, it has its roots in this school of thought. Although few strategy researchers have clearly cited this school of 


\section{Al Macrothink}

Business and Economic Research ISSN 2162-4860 2013, Vol. 3, No. 1

thought, but the impact of the Austrian thinking is much broader than its external manifestation. Development of concepts such as continuous innovation, flexibility, unstable heterogeneity and the effects of invisible factors on business performance in the literature of strategy bespeaks of the expansion of Austrian attitude to the field of strategy (Clarkson and Hodgkinson 2005).

In other hand, Structural Equation Modeling (SEM) is a comprehensive statistical approach to testing hypotheses about relations among observed and latent variables. A major advantage of SEM is the ability to estimate a complete model incorporating both measurement and structural considerations. We tested the measurement and research models by applying a structural equation modeling (SEM) approach, using the computer software program LISREL 8.5 with 269 samples. We used a variety of indices to evaluate model fit. The four fit indices used and values indicating acceptable model fit include:

1. The ratio of the $\chi^{2}$ statistic to its degrees of freedom, with values of less than 3 indicating acceptable fit;

2. Root mean squared error of approximation (RMSEA), with values below 0.08 representing acceptable fit;

3. Goodness of fit index (GFI), with values exceeding 0.9 indicating good fit;

4. Adjusted GFI (AGFI), with values exceeding 0.8 indicating acceptable fit (Ngai et al., 2007).

\section{Research Methodology}

\subsection{Research Method}

Research method is used for this article is descriptive-correlation. This study was using second source (library and other recorded observations) data and case study. First we studied literature of Innovation, Insurance industry, and searches about them in Iran. After reviewing the literature and identification of indicators, 35 subsidiary factors of this structure were defined and after doing some interviews with experts, these factors decreased to 16 .

Then, a questionnaire among Iranian insurance industry's experts was distributed and 269 questionnaires were completed. At the end we utilize Factor Analysis (by SPSS 18 Software) and Structural Equation Modeling (by Lisrel 8.5 software) and analysis output was published.

\subsection{Statistical Population and Sample Size}

Statistical community of the study includes the Iranian insurance industry and academic experts who besides being familiar with insurance industry, have proper management and work experiences in this field.

In first Step, for identifying of indicators: Based on snowball sampling method and through several phases, 5 of industrial experts were selected to participate for identifying of indicators of innovation in the insurance industry which considering the previous research and their experience in this issue, the number of samples for extraction of qualitative model is appropriate. 
In second Step, for presenting Conceptual model: A questionnaire among Iranian insurance industry's experts was distributed and 269 questionnaires were completed.

The second questionnaire consisting multi- value questions with ordinal scale (five-point Likert items) and because the population is huge, so the following formula is used to calculate the sample. As far as there is no certainty to have a crucial effect, $\% 5$ is used which in this case the sample value is increased to its optimal.

In this research the according to level of certainty and precision are $\% 95$ and $\% 6$ respectively the sample value is calculated as following:

$$
n=\frac{Z_{\alpha / 2}^{2} \times p(1-p)}{\varepsilon^{2}}=\frac{(1.96)^{2} \times(0.5) \times(0.5)}{(0.06)^{2}} \cong 267
$$

Also for Fit of Goodness in factor analysis KMO is used. Moreover Cronbach's Alpha coefficient is used to examine the validity of the questionnaire. The Cronbach's alpha reliability for questionnaire is 0.879 that is more than $0.6(\alpha>0.6)$, which indicates all scales demonstrate good reliability. For evaluating validity of questionnaires, we used construct validity. Construct validity determines the extent to which a scale measures a variable of interest (Moon and Kim, 2001). In this research we used factor analysis for considering the structure of research. Exploring factor analysis and criteria factor was used to investigate construction of questionnaire. Factor analysis depicted that all mentioned criteria are measured in these questionnaires.

\subsection{Compiling the List of Concepts Related to Enterprise Innovation}

The first step is determining the issue studied and its related concepts. In order to adapt the list of concepts related to innovation and industrial environment of the country as well as requirements of insurance industry, the above-mentioned list was revised according to ideas derived from the study of theoretical principles (Table 1) in the panel of industrial experts (Chen et al., 2004; Clarkson and Hodgkinson, 2005; Jeong-dong and Chansoo, 2006; Zhong and Yang, 2007).

Table 1: Factors related to innovation derived from theoretical studies

\begin{tabular}{|c|c|c|c|c|c|}
\hline No. & Variables & No. & Variables & No. & Variables \\
\hline 1 & Market Dynamics & 13 & Goal Agreement & $\begin{array}{c}\text { Innovation } \\
\text { Commercialization }\end{array}$ \\
\hline 2 & $\begin{array}{c}\text { Technological } \\
\text { Dynamics }\end{array}$ & 14 & $\begin{array}{c}\text { Information and } \\
\text { Knowledge Sharing and } \\
\text { Integration }\end{array}$ & 26 & $\begin{array}{c}\text { Entrepreneurial } \\
\text { Climate }\end{array}$ \\
\hline 3 & Competition Intensity & 15 & $\begin{array}{c}\text { Coordination and } \\
\text { Communication } \\
\text { Mechanism }\end{array}$ & $\begin{array}{c}\text { Entrepreneurship } \\
\text { Strategy }\end{array}$ \\
\hline 4 & Strategic Orientation & 16 & $\begin{array}{c}\text { Cooperation and } \\
\text { Collaboration }\end{array}$ & 28 & $\begin{array}{c}\text { Entrepreneurial } \\
\text { Resources }\end{array}$ \\
\hline 5 & Human Capital & 17 & $\begin{array}{c}\text { Technical Integration } \\
\text { Mechanism }\end{array}$ & 29 & $\begin{array}{c}\text { Opportunity } \\
\text { Exploration }\end{array}$ \\
\hline
\end{tabular}




\begin{tabular}{|c|c|c|c|c|c|}
\hline 7 & $\begin{array}{c}\text { Manufacturing } \\
\text { Capability }\end{array}$ & 19 & Innovation Strategy & 31 & $\begin{array}{c}\text { Entrepreneurial } \\
\text { activities }\end{array}$ \\
\hline 8 & $\begin{array}{c}\text { Technological } \\
\text { Capability }\end{array}$ & 20 & $\begin{array}{c}\text { Innovation Management } \\
\text { System }\end{array}$ & 32 & $\begin{array}{c}\text { Innovative } \\
\text { Performance }\end{array}$ \\
\hline 9 & Marketing Capability & 21 & Innovation Resources & 33 & $\begin{array}{c}\text { Entrepreneurial } \\
\text { Performance }\end{array}$ \\
\hline 10 & $\begin{array}{c}\text { Knowledge and } \\
\text { Learning Capability }\end{array}$ & 22 & Product Innovation & 34 & 35 \\
\hline 11 & Relational Capability & 23 & Process Innovation & $\begin{array}{c}\text { Financial } \\
\text { Performance }\end{array}$ \\
\hline 12 & $\begin{array}{c}\text { Trust, Commitment and } \\
\text { Mutual Understanding }\end{array}$ & 24 & $\begin{array}{c}\text { Business System } \\
\text { Innovation }\end{array}$ \\
\hline
\end{tabular}

\subsection{List of Refined Innovation Related Factors}

In order to adjust the list of extracted factors from the theoretical literature and previous studies with the insurance industry environment, semi-structured interviews with 5 experts were done as a result of which a number of factors were deleted from, merged into, or added to the above list. The basis of agreement was meaningfulness of the above concepts in the insurance industry. Refined list of factors related to innovation is presented in the following Table.

Table 2: List of refined innovation related factors from the perspective of insurance industry experts

\begin{tabular}{|c|c|c|c|c|c|}
\hline Number & factor & Acronyms & Number & factor & Acronyms \\
\hline 1 & $\begin{array}{l}\text { Knowledge } \\
\text { management }\end{array}$ & KM & 9 & $\begin{array}{c}\text { Business System } \\
\text { Innovation } \\
\end{array}$ & BSI \\
\hline 2 & $\begin{array}{l}\text { Marketing } \\
\text { Capability }\end{array}$ & $\mathrm{MC}$ & 10 & $\begin{array}{c}\text { Innovation } \\
\text { Commercialization }\end{array}$ & ICO \\
\hline 3 & $\begin{array}{c}\text { Technological } \\
\text { Capability }\end{array}$ & $\mathrm{TC}$ & 11 & Innovation Climate & ICL \\
\hline 4 & Human Capital & $\mathrm{HC}$ & 12 & Innovation Strategy & IS \\
\hline 5 & $\begin{array}{c}\text { Entrepreneurial } \\
\text { Performance }\end{array}$ & EP & 13 & Product Innovation & PDI \\
\hline 6 & $\begin{array}{c}\text { Market } \\
\text { Performance }\end{array}$ & MP & 14 & $\begin{array}{l}\text { Competition } \\
\text { Intensity }\end{array}$ & $\mathrm{CI}$ \\
\hline 7 & $\begin{array}{c}\text { Financial } \\
\text { Performance }\end{array}$ & FP & 15 & $\begin{array}{c}\text { Technological } \\
\text { Dynamics }\end{array}$ & $\mathrm{TD}$ \\
\hline 8 & $\begin{array}{c}\text { Process } \\
\text { Innovation }\end{array}$ & PCI & 16 & Market Dynamics & MD \\
\hline
\end{tabular}

\section{Data Analysis}

Data analysis is accomplished by inferential statistics techniques particularly exploratory factor analysis and confirmatory factor analysis.

\subsection{The Results of Exploring Factor Analysis}

We considered 16 questions by factor analysis and based on 269 gathered questionnaires; $\mathrm{KMO}$ was 0.814 showing that the sample size was enough. Also considering the fact that sig. in Bartlett test was lower than 0.05, Also considering the fact that sig. in Bartlett test was lower 


\section{MlMacrothink}

Business and Economic Research

ISSN 2162-4860

2013, Vol. 3, No. 1

than 0.05 . The Total Variance Explained for the seven factors in the questionnaire was found to be $69.09 \%$, which explains the variance of the concept of "Corporate Innovation in the Insurance Industry (COI)", in fact indicating a high level of reliability for the questionnaire. The result of Exploratory Factor Analysis for the "Corporate Innovation in the Insurance Industry (COI)" model has been shown in Table 4.

Table 3: Rotated Component Matrix

\begin{tabular}{|c|c|c|c|c|}
\hline \multirow{2}{*}{$\begin{array}{c}\text { Factor Model } \\
\text { dimensions }\end{array}$} & $\begin{array}{c}\text { Innovation } \\
\text { Capability } \\
\text { (IC) }\end{array}$ & $\begin{array}{c}\text { Organizational } \\
\text { abilities and assets } \\
\text { (OAA) }\end{array}$ & $\begin{array}{c}\text { Compironmental } \\
\text { Factors (EF) }\end{array}$ & $\begin{array}{c}\text { Innovative } \\
\text { Performance } \\
\text { (IP) }\end{array}$ \\
\hline PCI & 0.637 & 0.402 & -0.133 & -0.198 \\
\hline BSI & 0.754 & 0.302 & 0.053 & 0.188 \\
\hline ICO & 0.794 & -0.022 & 0.137 & 0.182 \\
\hline ICL & 0.821 & 0.266 & -0.049 & 0.043 \\
\hline IS & 0.834 & 0.073 & 0.018 & 0.041 \\
\hline PDI & 0.821 & 0.075 & 0.174 & -0.038 \\
\hline EP & -0.013 & 0.179 & 0.058 & 0.836 \\
\hline MP & 0.119 & 0.129 & 0.166 & 0.836 \\
\hline FP & 0.077 & 0.408 & 0.267 & 0.640 \\
\hline KM & 0.052 & 0.532 & 0.217 & 0.367 \\
\hline MC & 0.255 & 0.832 & 0.162 & 0.155 \\
\hline TC & 0.333 & 0.528 & 0.415 & 0.250 \\
\hline HC & 0.258 & 0.788 & 0.153 & 0.270 \\
\hline CI & 0.037 & 0.014 & 0.834 & 0.181 \\
\hline TD & 0.097 & 0.155 & 0.641 & 0.178 \\
\hline MD & -0.007 & 0.298 & 0.024 \\
\hline
\end{tabular}

According to results in table 3, "Process Innovation", "Business System Innovation", "Innovation Commercialization", "Innovation Climate", "Innovation Strategy", and "Product Innovation" belong to the first factor namely "Innovation Capability (IC)" and are put in that category; while the other four variables "Knowledge management", "Marketing Capability", "Technological Capability" and "Human Capital" belong to the second factor namely "Organizational abilities and assets (OAA)", so they are put in that category; three variables namely coping with "Competition Intensity", "Technological Dynamics", and "Market Dynamics" belong to the third factor namely "Environmental Factors (EF)", so they are put in that category; three variables under the names of "Entrepreneurial Performance", "Market Performance", and be "Financial Performance" belong to the third factor namely "Innovative Performance (IP)",so they are put in that category; Exploratory factor analysis model is shown in Figure 1.

\subsection{The Results of Confirmatory Factor Analysis}

According to the exploratory factor analysis results, research main hypothesis is:

Main hypothesis $\left(\mathrm{H}_{1}\right)$ :"CCorporate Innovation in the Insurance Industry (COI)” is defined as a 


\section{Ml Macrothink}

Business and Economic Research ISSN 2162-4860 2013, Vol. 3, No. 1

higher-order construct which represents (a) Organizational abilities and assets, (b) Innovative Performance, (c) Innovation Capability, and (d) Environmental Factors.

And Research Sub hypothesizes are:

$\mathrm{H}_{1 \mathrm{a}}$ :"Organizational abilities and assets (OAA)" has a positive effect on "Corporate Innovation in the Insurance Industry".

$\mathrm{H}_{1 \mathrm{~b}}$ : "Innovative Performance (IP)" has a positive effect on "Corporate Innovation in the Insurance Industry".

$\mathrm{H}_{1 \mathrm{c}}$ :"Innovation Capability (IC)" has a positive effect on "Corporate Innovation in the Insurance Industry”.

$\mathrm{H}_{1 \mathrm{~d}}$ :"Environmental Factors (EF)" has a positive effect on "Corporate Innovation in the Insurance Industry".

The conceptual model incorporating the research hypotheses is shown in the following figure.

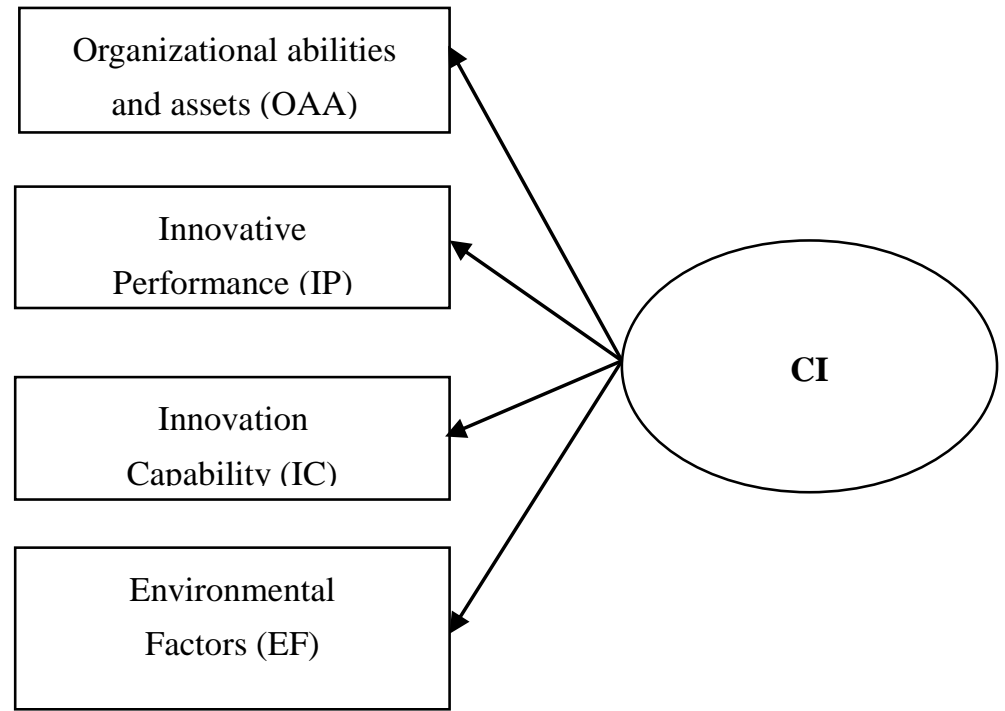

Figure1. Research proposed model

In the initial step we applied confirmatory factor analysis in Lisrel 8.5 and eventually conducted path diagram as per Figure 2. We have tested relationship between "Corporate Innovation in the Insurance Industry" latent and its indicators. Fitness's indices in Table 4 shows good fitness of our conceptual model, proving selected indicator are good representative for each dimension of "Corporate Innovation in the Insurance Industry (COI)". Also "Corporate Innovation in the Insurance Industry (COI)"is defined as a higher-order construct which represents (a) Organizational abilities and assets, (b) Innovative Performance, (c) Innovation Capability, and (d) Environmental Factors. So our main hypothesis (H1) and its Sub hypothesizes $\left(\mathrm{H}_{1 \mathrm{a}}, \mathrm{H}_{1 \mathrm{~b}}, \mathrm{H}_{1 \mathrm{c}}, \mathrm{H}_{1 \mathrm{~d}}\right)$ are supported.

Table 4: COI model fitness indices

\begin{tabular}{|c|c|}
\hline Fitness indices & Measure of Index \\
\hline Chi-Square/df & 2.3473 \\
\hline
\end{tabular}




\begin{tabular}{|c|c|}
\hline P-value & 0.000 \\
\hline $\begin{array}{c}\text { Root Mean Square Error of } \\
\text { Approximation (RMSEA) }\end{array}$ & 0.057 \\
\hline Goodness of Fit Index (GFI) & 0.94 \\
\hline Adjusted Goodness of Fit Index (AGFI) & 0.92 \\
\hline
\end{tabular}

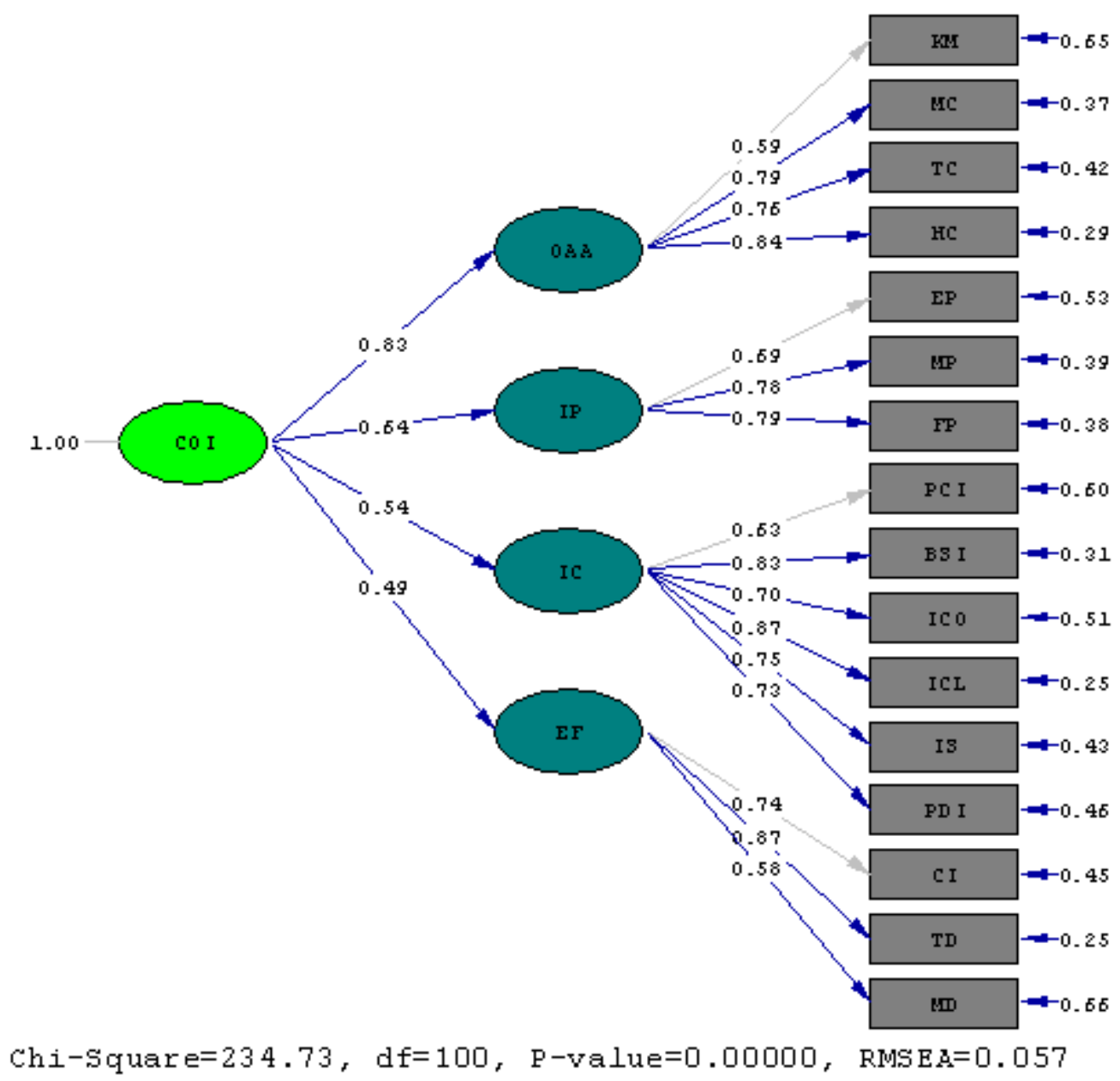

Figure 2. Standardized Solutions Model for COI

Figure 2 shows the extent each variable describes "Corporate Innovation in the Insurance Industry (COI)". The ranking of the variables is as follows: 1. Organizational abilities and assets (OAA), 2. Innovative Performance (IP), 3.Innovation Capability (IC), 4.Environmental Factors (EF).

Also, the followings are the results of figure 2:

1. The significant factors in "Organizational abilities and assets (OAA)" is HC with the correlation coefficient of $84 \%$, which is "Human Capital". Also, MC with the correlation coefficient of $79 \%$ is of great importance, which is "Marketing Capability".

2. The significant factor in "Innovative Performance (IP)" is FP with the correlation coefficient of $79 \%$, which is "Financial Performance". Also, MP with the correlation coefficient of $78 \%$ is of great importance, which is "Market Performance". 
3. The significant factor in "Innovation Capability (IC)" is ICL with the correlation coefficient of $87 \%$, which is "Innovation Climate". Also, BSI with the correlation coefficient of $83 \%$ is of great importance, which is "Business System Innovation".

4. The significant factor in "Environmental Factors (EF)" is TD with the correlation coefficient of $87 \%$, which is "Technological Dynamics". Also, CI with the correlation coefficient of $74 \%$ is of great importance, which is "Competition Intensity".

\section{Summary and Concluding Remarks}

The insurance industry is as evolution of global business trend for ICT-based Products in recent decades shows the intensive activity of pioneer developing countries for gain a powerful competitive position in global software industry. In this research, with regard to importance of competition issue for top managers of Iranian software companies, a conceptual model has been developed for Corporate Competitive Capability concept.

The aim of this paper, is presenting a conceptual model for "Corporate Innovation in the Insurance Industry" in the Iranian Insurance Industry. Statistical community of this research includes Iranian insurance industry and academic experts.

Firstly, by studying the literature and background of the subject, 35 subsidiary factors of this structure were defined and after doing some interviews with experts, these factors decreased to 16. Then, questionnaires were distributed among Iranian insurance industry's experts. Then, 269 filled questionnaires were collected. Next, Factor Analysis and Structural Equation Modeling were used to discover the conceptual model. Data analysis is accomplished by inferential statistics techniques particularly exploratory factor analysis and confirmatory factor analysis.

According to our results, "Process Innovation", "Business System Innovation", "Innovation Commercialization", "Innovation Climate", "Innovation Strategy", and "Product Innovation" belong to "Innovation Capability (IC)"; while the other four variables "Knowledge management", "Marketing Capability", "Technological Capability" and "Human Capital" belong to the second factor namely "Organizational abilities and assets (OAA; three variables namely coping with "Competition Intensity", "Technological Dynamics", and "Market Dynamics" belong to the third factor namely "Environmental Factors (EF) and "Entrepreneurial Performance", "Market Performance", and be "Financial Performance" belong to "Innovative Performance (IP)".

As a result, the proposed model was extracted. Our finding has been the design and modeling of factors affecting innovation performance of firms in the insurance industry. There are important managerial implications obtained from the findings. According to research findings, "Corporate Innovation in the Insurance Industry" is defined as a higher-order construct which represents (a) Organizational abilities and assets, (b) Innovative Performance, (c) Innovation Capability, and (d) Environmental Factors. Finally, we found that:

The significant factors in "Organizational abilities and assets" are "Human Capital" and "Marketing Capability". 


\section{MInstitute Macrothink $_{\text {Int }}$}

Business and Economic Research ISSN 2162-4860 2013, Vol. 3, No. 1

The significant factors in "Innovative Performance" are "Financial Performance" and "Market Performance".

$\checkmark$ The significant factors in "Innovation Capability" are "Innovation Climate and "Business System Innovation".

$\checkmark$ The significant factors in "Environmental Factors" are "Technological Dynamics" and "Competition Intensity".

Findings in this research are increasing our knowledge about Corporate Innovation in the Insurance Industry. For future studies we suggest more empirical studies in different countries. Also we suggest that researchers consider relationships between "Corporate Innovation" with investigating key elements in business environment (like, Business sophistication, Market size, Technological readiness, and financial market sophistication).

\section{References}

Chen, J., Zhu, Z. Xie, \& Y., H. (2004). Measuring intellectual capital: a new model and empirical study, Journal of Intellectual capital, 5(1), 85-100. http://dx.doi.org/10.1108/14691930410513003

Clarkson, G. P., \& Hodgkinson, G. P. (2005). Introducing CognizerTM: a comprehensive computer package for the elicitation and analysis of cause maps, Organizational Research Methods , 8(3), 317-341. http://dx.doi.org/10.1177/1094428105278022

Jeong-dong Lee \& Chansoo Park. (2006). Research and development linkages in a national innovation system: Factors affecting success and failure in Korea, Technovation, 26(9), 1045-1054.

Langfield-Smith K. M., \& Wirth A. (1992). Measuring differences between cognitive maps, Journal of the Operational Research Society, 43, 1135-1150.

Loalie, Thomas \& Telia Albert (2006). Innovation Management, translated by Manouchehr Ansari and AmirsamanKheirkhah, Industrial Management Organization Publications, Tehran.

Moon, J-W., \& Kim, Y-G. (2001). Extending the TAM for a World-Wide-Web context, Information \& Management, 38, 217-30. http://dx.doi.org/10.1016/S0378-7206(00)00061-6

Ngai, E. W. T., Poon, J. K. L., \& Chan, Y. H. C. (2007). Empirical examination of the adoption of WebCT using TAM, Computers \& Education, 48, 250-67. http://dx.doi.org/10.1016/j.compedu.2004.11.007

Nicksir, Fariba. (2007). Oslo Manual: Guidelines of Economic Cooperation and Development Organization for Collecting and Interpreting Innovation Data, Iranian Science Policy Research Center Publications, Tehran.

OECD. (2004). Organization for Economic Co-operation and Development, Oslo Manual.

Shu-Hsien Liao, Chia-Lin Hsieh \& Sui-Ping Huang (2008). Mining product maps for new product development, Expert Systems with Applications, 34(1), 50-62. http://dx.doi.org/10.1016/j.eswa.2006.08.027

Zhong, Xiwei \& Yang, Xiangdong. (2007). Science and technology policy reform and its 


\section{Macrothink}

Business and Economic Research ISSN 2162-4860 2013, Vol. 3, No. 1

impact on China's national innovation system, Technology in Society, 29(3), 317-325.

\section{Copyright Disclaimer}

Copyright reserved by the author(s).

This article is an open-access article distributed under the terms and conditions of the Creative Commons Attribution license (http://creativecommons.org/licenses/by/3.0/). 